\title{
Numerical modeling of steel-concrete composite beams
}

\section{Modelagem numérica de vigas mistas aço-concreto}
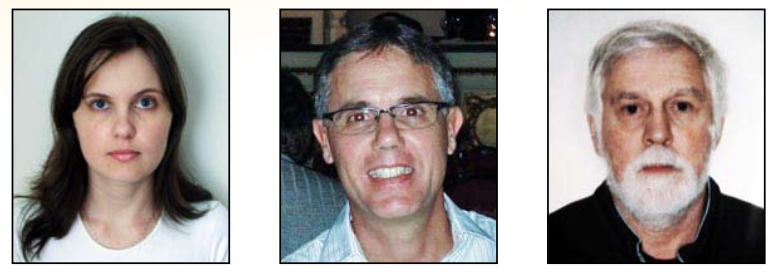

L. R. MARCONCIN a

liliane.m@ufpr.br

R. D. MACHADO ${ }^{b}$

rdm@ufpr.br

M. A. MARINO ${ }^{\circ}$

marino@ufpr.br

\begin{abstract}
The use of composite structures is increasingly present in civil construction works. Steel-concrete composite beams, particularly, are structures consisting of two materials, a steel section located mainly in the tension region and a concrete section, located in the compression cross sectional area, both connected by metal devices known as shear connectors. The main functions of these connectors are to allow for the joint behavior of the beam-slab, to restrict longitudinal slipping and uplifting at the elements interface and to take shear forces. This paper presents 3D numerical models of steel-concrete composite beams to simulate their structural behavior, with emphasis on the beam-slab interface. Simulations were carried out using version 10.0 ANSYS code, based on the Finite Element Method. The results obtained were compared with those provided either by Standards or found in the literature, and such comparison demonstrated that the numerical approach followed is a valid tool in analyzing steelconcrete composite beams performance.
\end{abstract}

Keywords: composite beams, shear connectors, numerical modeling, finite element (EF).

\section{Resumo}

A utilização de estruturas mistas está cada vez mais presente nas obras de Engenharia Civil. As vigas mistas, em particular, são estruturas compostas por dois materiais, um perfil metálico, situado em região predominantemente tracionada, e uma seção de concreto, situada em região predominantemente comprimida, ligados entre si através de dispositivos metálicos denominados de conectores de cisalhamento. As funções principais dos conectores são: permitir o trabalho solidário da laje-viga, restringir o escorregamento longitudinal e o deslocamento vertical na interface dos elementos e, absorver forças de cisalhamento. Nesse contexto, apresentam-se neste trabalho, modelos numéricos tridimensionais de vigas mistas aço-concreto, com a finalidade de simular o seu comportamento estrutural, enfatizando a interface laje-viga. As simulações foram feitas através do software ANSYS versão 10.0, que tem como base o Método de Elementos Finitos. Os resultados obtidos foram comparados com os previstos por norma e com referências encontradas na revisão bibliográfica, verificando-se que a modelagem numérica é uma ferramenta válida para a análise de vigas mistas aço-concreto.

Palavras-chave: vigas mistas, conectores de cisalhamento, modelagem numérica, elementos finitos (EF) .

a L. R. MARCONCIN. Universidade Federal do Paraná, Centro de Estudos de Engenharia Civil. liliane.m@ufpr.br. Prof. Inaldo Ayres Vieira - Centro Politécnico. Jardim das Américas. Caixa Postal 19.011 - CEP: 81.531-980 - Curitiba, PR;

b R. D. MACHADO. Universidade Federal do Paraná, Centro de Estudos de Engenharia Civil. rdm@ufpr.br. Prof. Inaldo Ayres Vieira - Centro Politécnico. Jardim das Américas. Caixa Postal 19.011 - CEP: 81.531-980 - Curitiba, PR;

c M. A. MARINO. Universidade Federal do Paraná, Centro de Estudos de Engenharia Civil. marino@ufpr.br. Prof. Inaldo Ayres Vieira - Centro Politécnico. Jardim das Américas. Caixa Postal 19.011 - CEP: 81.531-980 - Curitiba, PR. 


\section{Introduction}

\subsection{General aspects}

The composite steel-concrete systems were first used in the middle of the last century. They involve the joint work of concrete elements and steel sections, interacting mechanically by means of connectors, dents or bumps, either by friction or adhesion.

Generally, composite beams are made out of a combination of a steel section (commonly "l" shaped), located on predominantly tensioned region, with a concrete slab, positioned in predominantly compressed area. The mechanical binding is provided by metal devices called shear connectors. The main functions of the shear connectors are to allow for the joint work of the slab-beam new material [10], restricting longitudinal slip and vertical displacements of the interface elements, and to take shear forces [3].

By combining steel and concrete this way, it is possible to obtain the advantages of both materials working together [8]. Therefore, from the materials strength point of view, it is possible to take advantage of the steel section to take tension stresses and of the concrete in order to withstand compressive stresses [10]. This combination results in high stiffness and smaller structural sections [10], lighter foundation design, gains in materials performance and reduced costs. In addition, composite systems allow for the occasional elimination of formwork and shoring, and may reduce steel protection against fire and corrosion, due to the presence and adequate behavior of concrete in the system.

In Brazil, the first structures making use of composite systems were built in the 50s. However, in the last twenty years, a growth in steel production [4], as noticed by a bigger supply of steel sections in the domestic market, caused composite systems to increase drastically.

Having this picture in mind, this article focus numerical analysis of composite beams. The main idea is to make use of the computer program ANSYS [1], which is based on the Finite Element Method.

\subsection{Purpose}

The objective is to verify the influence of the amount, diameter and height of shear connectors in composite beams. These verifications were made by means of the analysis of longitudinal slip in the slab-beam interface, the vertical displacement at mid-span and the bearing capacity of composite beams. The results were compared to those provided by standards and to other data found in the consulted literature.

\section{Numerical modeling}

This paper uses models for composite beams, particularly the "A3", extracted from experimental tests [6] and numerical applications [11]. The tested model here presented, developed by a researcher [11], uses the same geometry, parameters, material properties and nomenclature of the composite beam defined in the referenced work.

Despite the methodology applied here is broad and general, the "A3" model simulated in this paper refers solely to the simply supported composite beam (Figure 1). It was defined as having solid web, full interaction between the slab and the steel section provided a by number of shear connectors calculated to prevent slipping

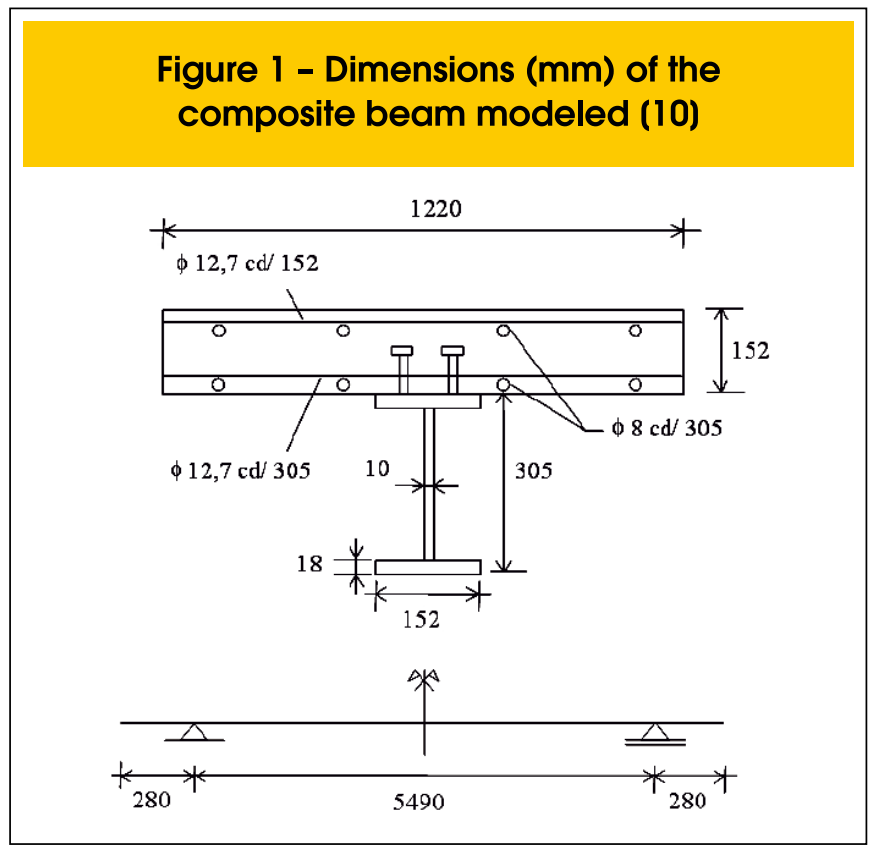

between the surfaces, flat concrete slab with two way reinforcement (transverse and longitudinal), shear connectors with pin-type head (stud bolt) and subjected to a point load in the mid span. The model was based on the finite element method, also used by other researchers [7], [10], [11] [14] and [15].

The model implementation started with the definition of the geometry of the composite beam (Figure 1). Secondly, finite elements available in the ANSYS [1] computer program library, were chosen to represent the composite materials. Thirdly, the properties and constitutive relations of the materials involved were introduced. Finally, the mesh, couplings and linkages between the elements were added, taking into consideration the symmetry condition and the consequent restriction of degrees of freedom, and also the beam support conditions and the applied load.

The first simulation was done vis-à-vis the unique characteristic of the A3 beam, to validate the model. Then, to analyze the connectors influence on the structural behavior of the composite beam, several alternatives for connectors were analyzed, with diameters ranging from $16 \mathrm{~mm}, 19 \mathrm{~mm}$ and $22 \mathrm{~mm}$ and heights from $76 \mathrm{~mm}$, $88 \mathrm{~mm}$ and $102 \mathrm{~mm}$. Lastly, the number of connectors recommended by the standard [2] was used, following the calculation procedure available in [12].

\subsection{Finite elements}

The definition of the proposed numerical model was made by using finite elements available in the ANSYS code default library [1].

The three-dimensional elements SOLID 65 were adopted to discretize the concrete slab, which are also able to simulate cracking behavior of the concrete under tension (in three orthogonal directions) and crushing in compression, to evaluate the material non-linearity and also to enable the inclusion of reinforcement (reinforcement bars scattered in the concrete region).

The representation of the steel section was made by the SHELL 43 elements, which allow for the consideration of non-linearity of 


\section{Table 1 - Characteristics of the beam and materials properties}

\section{Beam Model A3}

Number of connectors

Diameter of the connector body $(\mathrm{mm})$

Total height of connector ( $\mathrm{mm}$ )

External Load

$\mathrm{f}_{\mathrm{cm}}$ cylinder $\left(\mathrm{kN} / \mathrm{cm}^{2}\right)$

$E_{c m}\left(k N / c^{2}\right)$

$\mathrm{E}\left(\mathrm{kN} / \mathrm{cm}^{2}\right)$

$\mathrm{f}_{\mathrm{y}}\left(\mathrm{kN} / \mathrm{cm}^{2}\right)$

$\mathrm{f}_{\mathrm{u}}\left(\mathrm{kN} / \mathrm{cm}^{2}\right)$

$\mathrm{E}\left(\mathrm{kN} / \mathrm{cm}^{2}\right)$

$\mathrm{f}_{\mathrm{u}}\left(\mathrm{kN} / \mathrm{cm}^{2}\right)$

$\mathrm{f}_{\mathrm{y}}\left(\mathrm{kN} / \mathrm{cm}^{2}\right)$

$\mathrm{E}\left(\mathrm{kN} / \mathrm{cm}^{2}\right)$

$\mathrm{f}_{\mathrm{y}}\left(\mathrm{kN} / \mathrm{cm}^{2}\right)$

Soul
Table
Soul
Table
Soul
Table

Reinforcement
68

19

102

Concentrated of mid-span

1,84

2.642

19.456

20.064

30,2

25,2

44,4

44,7

20.500

51,4

42,1

20.500

32,0 the material and show linear deformation on the plane in which it is present.

The modeling of the shear connectors was done by the BEAM 189 elements, which allow for the configuration of the cross section, enable consideration of the non-linearity of the material and include bending stresses.

The TARGE 170 and CONTA 173 elements were used to represent the contact slab-beam interface. These elements are able to simulate the existence of pressure between them when there is contact, and separation between them when there is not. The two material contact also take into account friction and cohesion between the parties.

\subsection{Materials properties}

The characteristics of the "A3" beam and the real properties of materials are presented in Table 1. It is noteworthy mentioning that this study also considered other configurations for the connectors, as number, height and diameter.

\subsection{Constitutive relations}

It was considered that the steel section has a multilinear elasticplastic constitutive relationship with an isotropic hardening consideration, associated with the von Mises' plasticity criterion. The stress-strain curve followed the constitutive model presented in [9] and it was used in [15] and [7], as shown in Figure 2.

The adopted model for the steel connectors is a bi-linear isotropic hardening, also associated with von Mises' plasticity criterion. Figure 3 shows the stress-strain diagram for the steel connectors.

The constitutive relationship for the steel reinforcement follows a perfect elasto-plastic model and it is also associated with von Mis- es' plasticity criterion, based on the relationship between uniaxial tensions and their respective plastic deformations, as shown in the stress-strain diagram in Figure 4.

For the concrete slab, the constitutive tension relationship followed the CONCRETE model, provided by ANSYS [1], which is based on the Willam-Warnke solution and allows for the material cracking. This model was also used in [7] and [15]. For the concrete in compression, on the other hand, von Mises' laminating criterion was adopted. The model represents the behavior of a multilinear isotropic concrete hardening, given by the stress-strain diagram in Figure 5.

The solution for the contact between the concrete slab, the steel section and the connectors made use of the Pure Lagrange Multi-

\section{Figure 2 - Constitutive relation for the steel profile (8)}

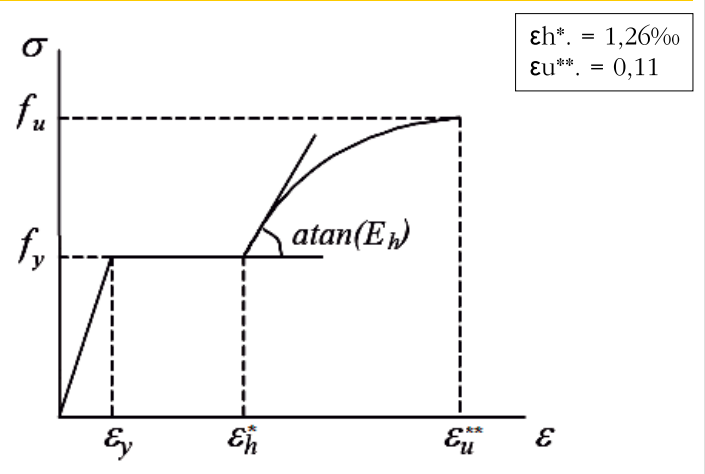




\section{Figure 3 - Constitutive relation for the shear connectors (10)}

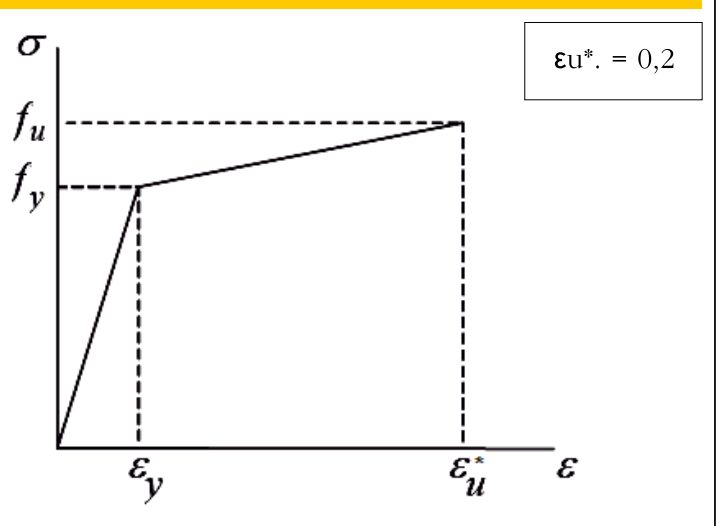

Figure 4 - Constitutive relation for the steel of the reinforcement (10)



\section{Figure 5 - Constitutive relation for the concrete (10)}

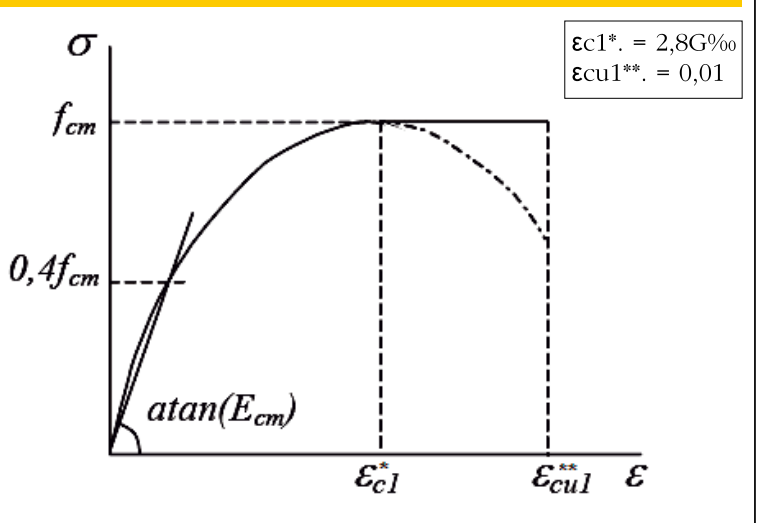

plier method, also provided by ANSYS [1]. This method assumes that there is no interpenetration between the two materials when the contact is closed and also that the slip is null, as long as it does not reach the shear stress limit [11]. The parameters that define if the contact is open or closed are set by FTOLN, which refers to a minimum value of penetration as to presume that the contact is closed and TNOP, which refers to a minimum value of normal tension to the contact surface, so that the status changes to open. The absolute value adopted for FTOLN was $-0.01 \mathrm{~cm}$. For the TNOP the value adopted was $0.18 \mathrm{kN} / \mathrm{cm}^{2}$. The established value of the friction coefficient between steel and concrete was 0.4 and, for cohesion, an estimated number of $0.18 \mathrm{kN} / \mathrm{cm}^{2}$ was taken from average values of adhesion tension related to the initial slip of the interface.

\subsection{Finite elements mesh}

The model designed for the numerical analysis was defined by four types of elements that form the concrete slab with added reinforcements, such as steel beam, shear connectors and the pair of contact at the slab-beam interface. The elements were established separately, but the nodes were one by one coupled on the interface between them.

The finite element mesh developed for all elements followed the same methodology and degree of refinement presented in [11]. Figure 6 shows the finite element mesh for the components cited, where (a) corresponds to the concrete slab, (b) to the steel beam, (c) to the shear connectors and (d) to the pair.

\subsection{Couplings and linkages}

The couplings connecting the elements consider the nodes superposition, with the degrees of freedom adapted, as illustrated in Figure 7.

The contact between the slab and the beam was established by the CONTA 173 elements, attached to the section web, and TARGE 170, attached to the inferior surface of the slab. The beamconnector link was considered as a clamped metal pin in the steel section, with rotations and translations made compatible. On the slab-connector interface, translational referring to the $X$ and $Z$ axis were also made compatible and, at the node below the pin head, there was a consideration of coupling in the $Y$ direction to represent the mechanical anchoring between the head of the connector and the concrete slab.

Attempting to reproduce a movable type support, the degrees of freedom related to the translation in $\mathrm{X}$ and the rotation in $\mathrm{Z}$ were not restricted at referred nodes of the composite beam support. At the nodes of the central section of the composite beam, a symmetry condition was applied, also provided by ANSYS [1] and, consequently, a restriction of degrees of freedom. Figure 8 shows the symmetry condition, the binding of the composite support beam in detail, and also the coupling between the materials.

When applying mixed beams loading without shoring, it was assumed that the steel section would support its dead weight and that the recently set concrete on the table would not have joint between the two materials. The behavior as a composite beam would only occur after the concrete curing, when it would be possible to apply an external load, because the composite beam would have reached the expected resistance as set in the project. Thus, by the 


\section{Figure 6 - Finite elements mesh}
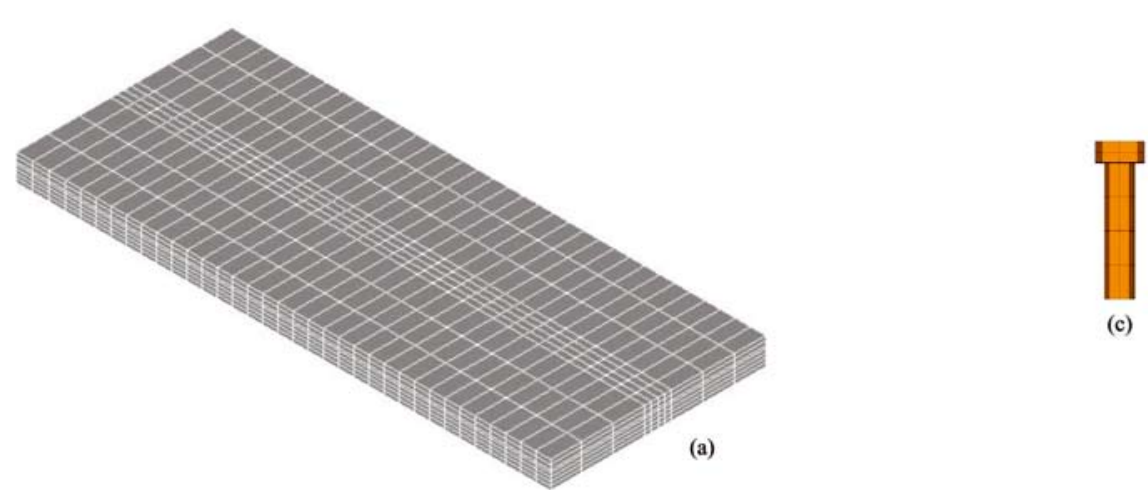

(c)
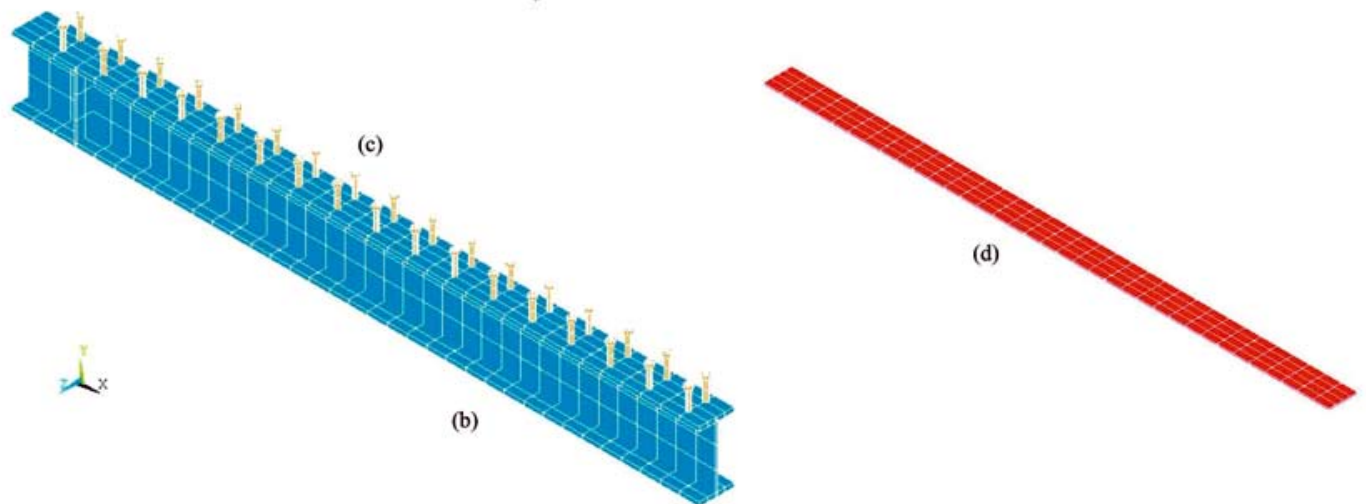

\section{Figure 7 - Coupling between elements}

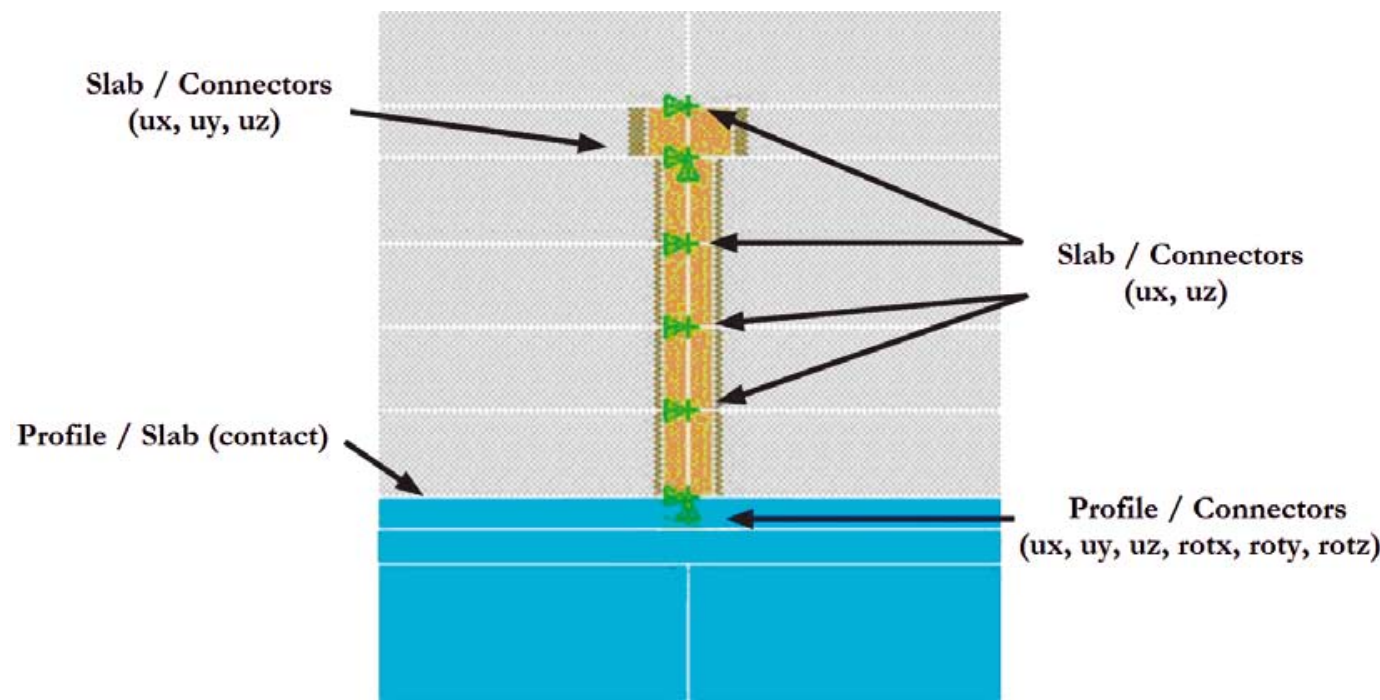




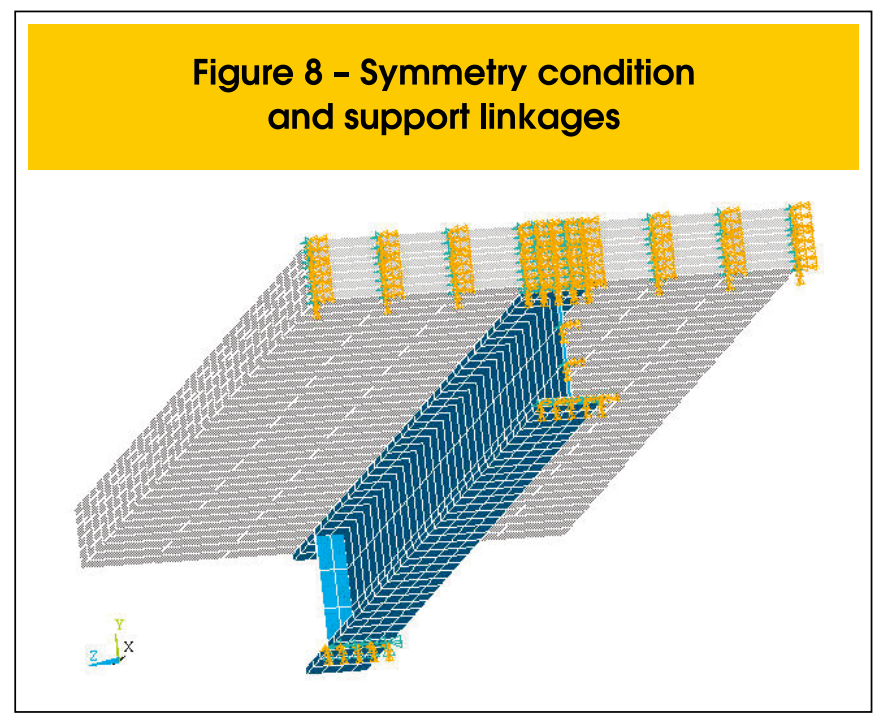

time it would start acting as a composite beam, the structure would already be deformed.

In this context, to simulate the loading application in beam A3, the Birth \& Death's technique, available in ANSYS [1], was adopted. This technique, which allows for elements activation and inactivation of a discretized mesh, consists of the multiplication of the value of the inactivated entity in the stiffness matrix and a reduction factor, which practically blocks the effects of the results of such entity. In this paper the adopted reduction factor was $10^{-6}$. Firstly, the concrete slab and the shear connectors were inactivated and the structure dead weight was applied to the steel section. Secondly, the concrete slab was activated and the applied load was used in regard of the solidarity slab-beam work. The structure dead weight was inputted into the modeling according to the unit weight of the materials, which were: $24 \mathrm{kN} / \mathrm{m}^{3}$ for the concrete and $77 \mathrm{kN} / \mathrm{m}^{3}$ for the steel girder, connectors and reinforcements. The applied load was incrementally and monotonically included immediately after the action of the dead weight of the composite beam. Although concentrated in the middle of the span, the load was considered

\section{Figure 9 - External load on composite beam}

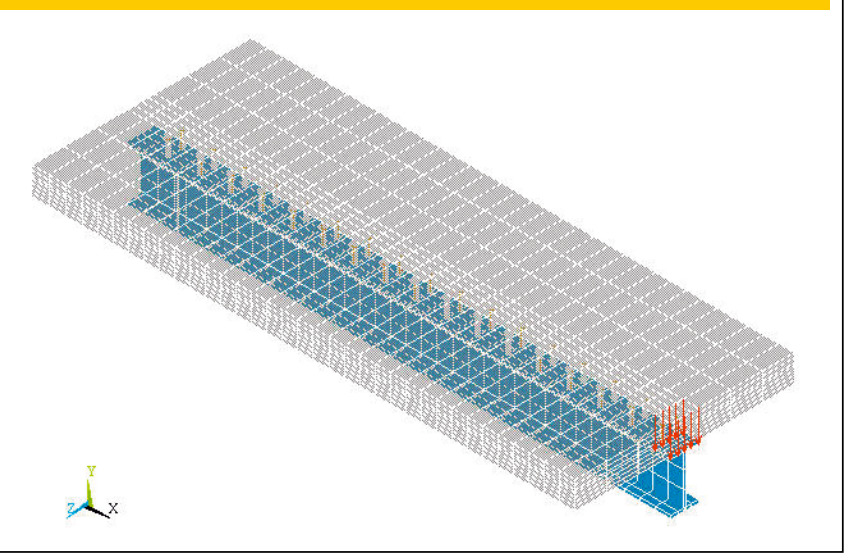

as spread throughout a small area, applied at the nodes of the upper surface of the concrete slab, centered on the axis of the beam, according to the experimental model presented in [6]. Both the structure dead load and the applied load were included incrementally in the model to take into account the nonlinear behavior of the materials that form the composite beam.

Figure 9 shows the composite beam with an applied load concentrated on the mid-span.

\section{Results and discussions}

Figure 10 shows comparative results of vertical displacements at midspan (a) and longitudinal sliding (slab-beam) at the end of the beam (b), with the increment of the applied load. These results refer to the first stage of the simulation and compare well with values experimentally [6] obtained and numerically presented in [11] and in this work. It is noteworthy that the computational model developed in [11] took into consideration shored composite beams, while this work and the experimental tests shown in [6] deal with non shored composite beams.

\section{Figure 10 - Graphics force versus vertical displacement (a) and force versus slid (b) to A3 beam}

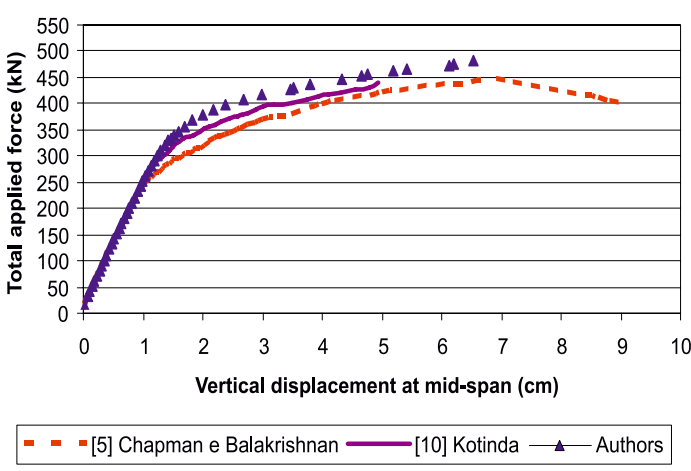

(a)

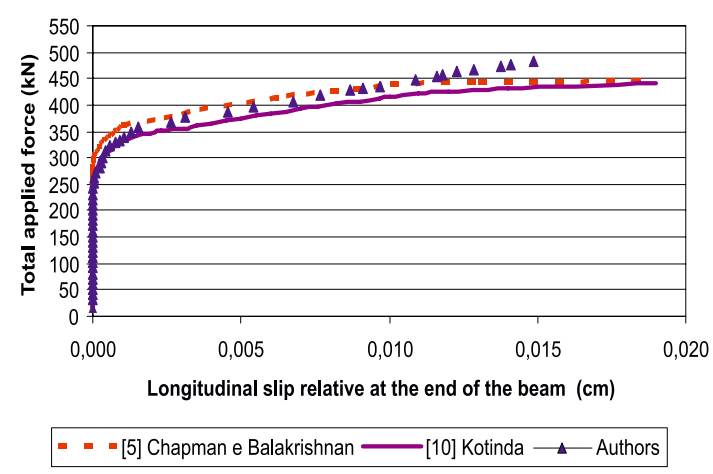

(b) 
Table 2 - Summary of the results considering variations of $H$

\begin{tabular}{ccccc} 
Parameter & $\varnothing(\mathrm{mm})$ & $\mathrm{F}_{\max }(\mathrm{kN})$ & $\mathrm{u}_{\max }(\mathrm{cm})$ & $\mathrm{d}_{\max }(\mathrm{cm})$ \\
$\mathrm{H}=76 \mathrm{~mm}$ & & 506.90 & 9.24 & 0.0188 \\
$\mathrm{H}=88 \mathrm{~mm}$ & 19 & 481.32 & 6.48 & 0.0143 \\
$\mathrm{H}=102 \mathrm{~mm}$ & & 481.46 & 6.54 & 0.0149 \\
\hline
\end{tabular}

Table 3 - Summary of results considering the influence of changes in $\varnothing$

\begin{tabular}{lcccc|} 
Parameter & $\mathrm{H}(\mathrm{mm})$ & $\mathrm{F}_{\max }(\mathrm{kN})$ & $\mathrm{u}_{\max }(\mathrm{cm})$ & $\mathrm{d}_{\max }(\mathrm{cm})$ \\
$\varnothing=16 \mathrm{~mm}$ & 102 & 437.68 & 3.84 & 0.0133 \\
$\varnothing=19 \mathrm{~mm}$ & 102 & 481.46 & 6.54 & 0.0149 \\
$\varnothing=22 \mathrm{~mm}$ & 102 & 506.28 & 9.29 & 0.0151 \\
\hline
\end{tabular}

Table 4 - Summary of comparative results considering the variations of NC with $\mathrm{H}$

\begin{tabular}{|c|c|c|c|c|c|}
\hline \multicolumn{2}{|c|}{ Parameter } & $\varnothing(\mathrm{mm})$ & $F_{\max }(k N)$ & $\mathbf{u}_{\max }(\mathrm{cm})$ & $d_{\max }(\mathrm{cm})$ \\
\hline $\begin{array}{c}\mathrm{NC}=68 \\
\downarrow N C=46^{*}\end{array}$ & $\mathrm{H}=76 \mathrm{~mm}$ & & $\begin{array}{c}506,90 \\
\downarrow 466,78\end{array}$ & $\begin{array}{c}9,24 \\
\downarrow 4,80\end{array}$ & $\begin{array}{c}0,0188 \\
\downarrow 0,0255\end{array}$ \\
\hline $\begin{array}{c}N C=68 \\
\downarrow N C=46^{*}\end{array}$ & $\mathrm{H}=88 \mathrm{~mm}$ & 19 & $\begin{array}{c}481,32 \\
\uparrow 488,12\end{array}$ & $\begin{array}{c}6,48 \\
\downarrow 6,07\end{array}$ & $\begin{array}{c}0,0143 \\
\downarrow 0,0329\end{array}$ \\
\hline $\begin{array}{c}\mathrm{NC}=68 \\
\text { @ } \mathrm{NC}=46^{*}\end{array}$ & $\mathrm{H}=102 \mathrm{~mm}$ & & $\begin{array}{c}481,46 \\
@ 502,30\end{array}$ & $\begin{array}{c}6,54 \\
@ 7,22\end{array}$ & $\begin{array}{c}0,0149 \\
@ 0,0391\end{array}$ \\
\hline
\end{tabular}

Figure 10 shows that, under the elastic range, results for the composite beams are similar for both the experimental and numerical models. In the nonlinear range, the limit load of the simulated numerical model was $7.5 \%$ higher than the one for the experimental model, presented in [6], and $8.5 \%$ higher than the one for the numerical model, in [11].

Regarding the vertical displacement at the center of the span of the beams in the limit load, the value of the numerical model is $27 \%$ lower than the experimental one exposed in [6]. This suggests a more rigid behavior of the model developed in this work.

The analyzed slip, on the other hand, did not show the same behavior. At the limit load, the experimental [6] and numerical [11] model presented similar sliding, while the experimental model resulted in a sliding $20 \%$ lower.

Thus, it can be inferred that it is possible to represent numerically experimental models. It is likely that the differences found between the models are due to numerical instability, stemming from experimental models calibration because of the adopted parameters.

\subsection{Influence of connectors}

Table 2 displays the result of the influence of the connector height $(H)$ in the limit load $\left(F_{\text {max }}\right)$, in the vertical displacement at mid-span $\left(u_{\max }\right)$ and in the average relative longitudinal slip $\left(\mathrm{d}_{\max }\right)$ (between the slab and the steel section), at the end of the beam for the second stage of simulations. Maximum loading occurs for the connector with $\mathrm{H}=76 \mathrm{~mm}$. This solution was also the one which showed greater vertical displacement and longitudinal sliding; this suggests a more ductile behavior than others. Thus, it appears that increasing the height of the connector does not necessarily increases the load limit, the vertical displacement or the longitudinal sliding.

It is presented in Table 3 the result of the influence of the diameter of the connector $(\varnothing)$ in the limit load $\left(F_{\max }\right)$, in the vertical displacement at mid-span $\left(u_{\max }\right)$ and in the average relative longitudinal slip $\left(d_{\max }\right)$ (between the slab and the profile steel), at the end of the beam.

Table 3 shows that increasing the diameter of the connector increases the limit load, the vertical displacement and the longitudinal slip, whose highest value corresponds to the connector $\varnothing=22 \mathrm{~mm}$.

Table 4 shows the comparative result for the second and the third steps of the simulations for the influence of the numbers of connectors $(\mathrm{NC})$, with different heights $(\mathrm{H})$, in the limit load $\left(\mathrm{F}_{\max }\right)$, in the vertical displacement at mid-span $\left(u_{\max }\right)$ and in the average relative longitudinal slip $\left(\mathrm{d}_{\max }\right)$ (between the slab and the steel profile), at the end of the beam. 
Table 5 - Summary of comparative results considering the variations of NC with $\varnothing$

\begin{tabular}{|c|c|c|c|c|c|}
\hline \multicolumn{2}{|c|}{ Parameters } & $\varnothing(\mathrm{mm})$ & $\mathbf{F}_{\max }(\mathbf{k N})$ & $\mathbf{u}_{\max }(\mathrm{cm})$ & $\mathrm{d}_{\max }(\mathrm{cm})$ \\
\hline $\begin{array}{c}N C=68 \\
\downarrow N C=64^{*}\end{array}$ & $\varnothing=16 \mathrm{~mm}$ & & $\begin{array}{c}437.68 \\
\uparrow 471.54\end{array}$ & $\begin{array}{c}3.84 \\
\uparrow 6.16\end{array}$ & $\begin{array}{c}0.0133 \\
@ 0.0235\end{array}$ \\
\hline $\begin{array}{c}N C=68 \\
\downarrow N C=46^{*}\end{array}$ & $\varnothing=19 \mathrm{~mm}$ & 102 & $\begin{array}{c}481.32 \\
\uparrow 502.30\end{array}$ & $\begin{array}{c}6.48 \\
\uparrow 7.22\end{array}$ & $\begin{array}{c}0.0143 \\
@ 0.0391\end{array}$ \\
\hline $\begin{array}{c}N C=68 \\
\downarrow N C=34^{*}\end{array}$ & $\varnothing=22 \mathrm{~mm}$ & & $\begin{array}{c}481.46 \\
@ 487.42 \\
\end{array}$ & $\begin{array}{c}6.54 \\
@ 7.50 \\
\end{array}$ & $\begin{array}{c}0.0149 \\
@ 0.0423 \\
\end{array}$ \\
\hline
\end{tabular}

It may be noted from Table 4 that reducing the number of connectors $(\downarrow N C)$ results in an amplification $(\uparrow)$ of the longitudinal slip but, not necessarily, in the decrease $(\downarrow)$ of the maximum force and the increase of the vertical displacement.

Table 5 shows the comparative results of the second and third steps of the simulation for the influence of the number of connectors $(\mathrm{NC})$, with different diameters $(\varnothing)$, in the load limit $\left(\mathrm{F}_{\max }\right)$, in the vertical displacement at mid-span $\left(u_{\max }\right)$ and in the average relative longitudinal slip $\left(\mathrm{d}_{\max }\right)$ (between the slab and the steel section), at the end of the beam.

\section{Figure 11 - Graphics force versus displacement (a) and force versus slid (b) to connectors with $19 \mathrm{~mm}$ in diameter}

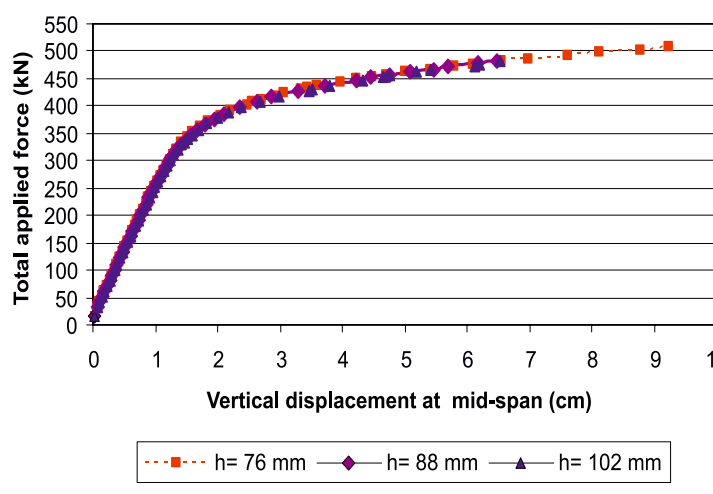

(a)

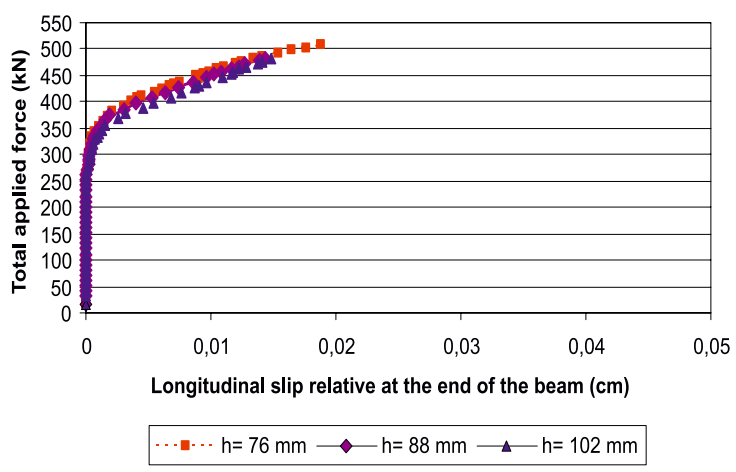

(b)

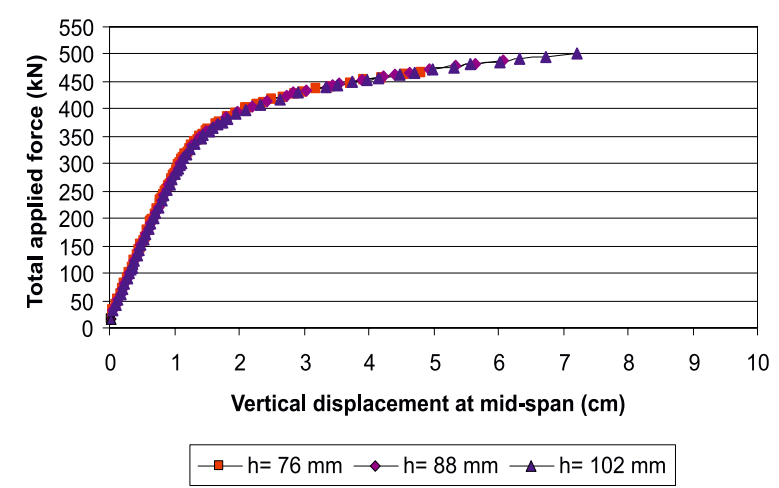

(a)

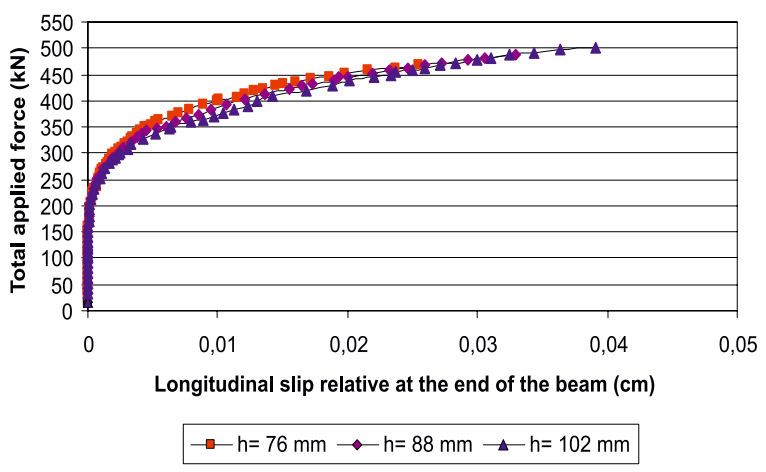

(b)

Authors

NBR 8800 


\section{Figure 12 - Graphics force versus displacement (a) and} force versus slid (b) to connectors with $102 \mathrm{~mm}$ high

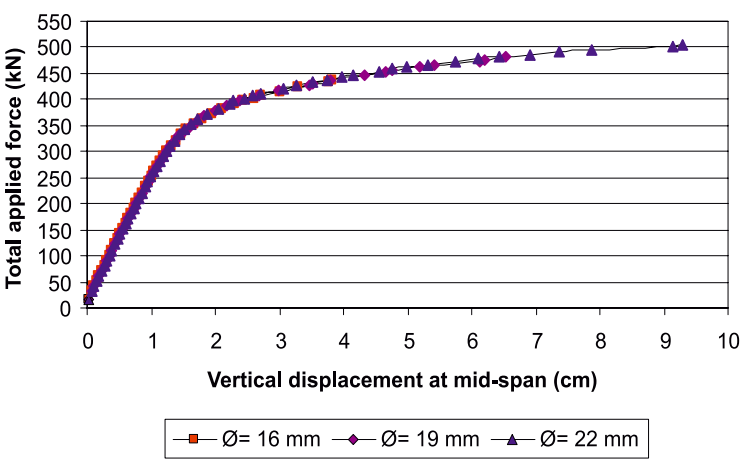

(a)

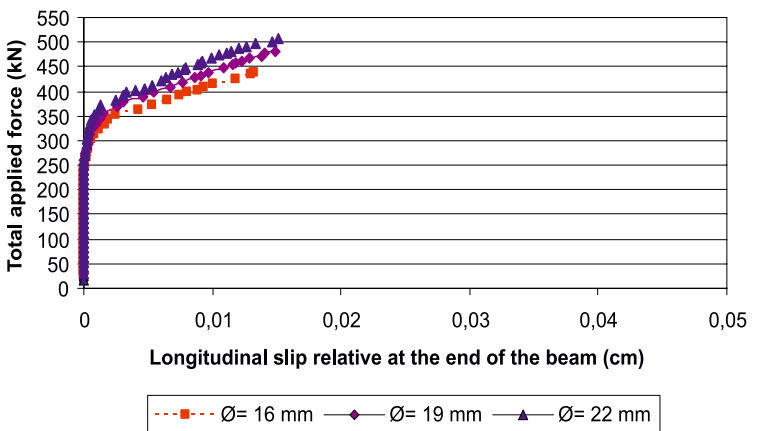

(b)

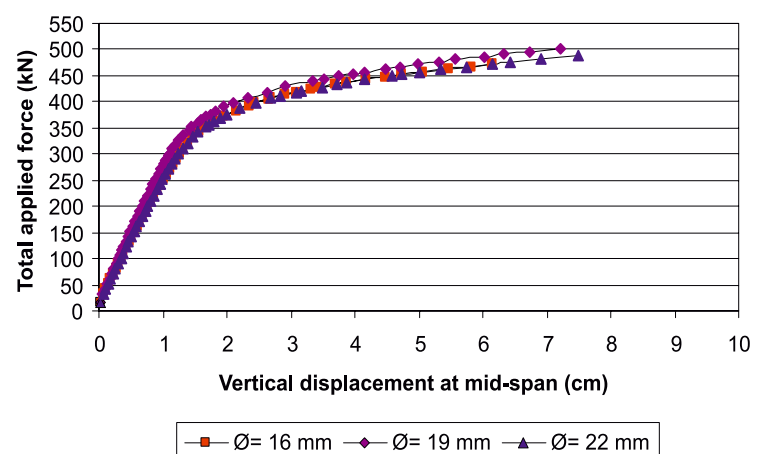

(a)

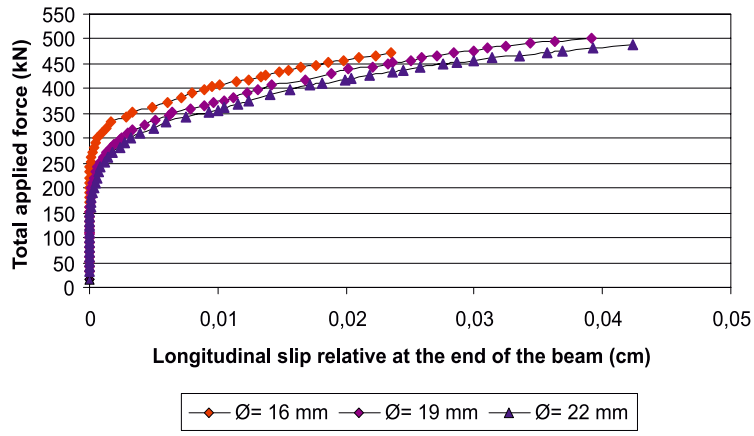

(b)

Authors

NBR 8800

It is possible to infer from Table 5 that the decrease $(\downarrow)$ of the number of connectors (NC) implies an increase $(\uparrow)$ of the vertical displacement and of the longitudinal sliding, but not neces- sarily, in a reduction $(\downarrow)$ of the maximal force.

To better visualize the data in Tables 2, 3, 4 and 5, Figures 11 and 12 display comparative graphics of steps two and three of the evo-

\section{Figure 13 - Types of cracking on slab due the concentrated force (6)}

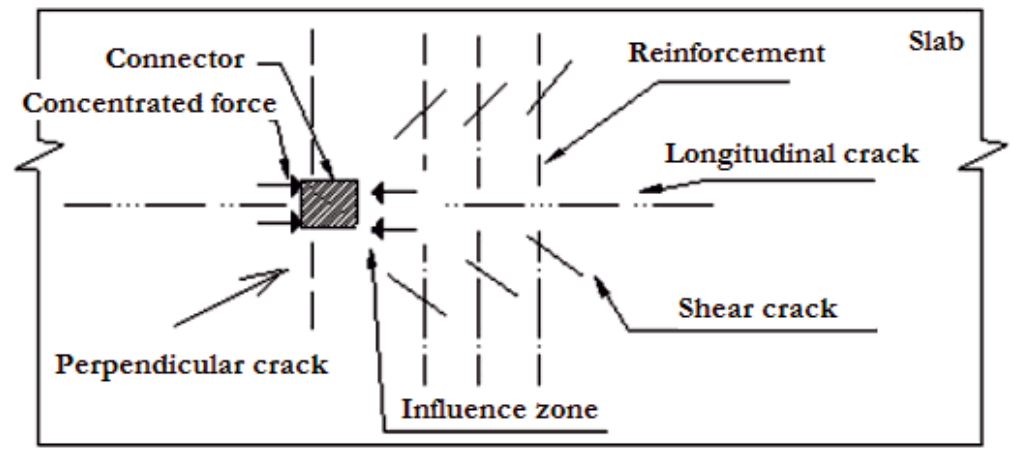


lution of vertical displacements at mid-span (a) and average relative longitudinal sliding (between the slab and the steel section), at the end of the composite beam (b) with the total force applied to the mixed system.

Figure 11 shows the comparative graphics of force versus displacement (a) and force versus slip (b) for beams with connectors $19 \mathrm{~mm}$ in diameter, and Figure 12 shows the comparative graphics of force versus displacement (a) and force versus slip (b) of composite beams with connectors $102 \mathrm{~mm}$ in height.

Figures 11 and 12 show that the behavior of composite beams in the elastic range were similar for all connectors, regardless their number, diameter and height. However, in the nonlinear range, the reduction in the number of connectors implies an increasing of the longitudinal slip and it has no preponderant influence on the force and on the vertical displacement.

Figures 14,15 and 16 show cracks in the elements of the concrete slab of the composite beam with connectors $19 \mathrm{~mm}$ in diameter and $102 \mathrm{~mm}$ in height.

According to the settings of ANSYS, the first crack occurring in the element is represented by a red circle, the second by a green circle and the third by a blue circle. These circles appear at the centroid of each element and are inclined according to the plane that contains the crack.

The cracking modes in the slab are due to a strength and stiffness reduction of the concrete in the triaxial compression zone as a consequence of concrete cracking caused by the connector, when it applies a concentrated force in the slab [10]. In Figure 13 it is possible to check the three modes of cracking occurring in the slab [13].

Figure 14 shows that the first cracks in the concrete slab elements were identified for an applied load equal to $101.35 \mathrm{kN}$.

Figure 15 shows the first cracks by shearing in the concrete slab elements, which were flagged for a loading level equal to $151.45 \mathrm{kN}$. Besides these cracks, it is possible to observe transverse cracks ( $Z$ direction) in the middle of the span of this figure.

The cracking of the concrete slab for the loading last step (481.46 $\mathrm{kN}$ ) is shown in Figure 16.

In the cracking of the concrete slab of the composite beam with connectors $19 \mathrm{~mm}$ in diameter and $102 \mathrm{~mm}$ in height, it was found that the first cracks (Figure 14) are in the slab-beam interface and appear to an applied load of $101.35 \mathrm{kN}$ due to the established adherence for the materials. For $151.45 \mathrm{kN}$ (Figure 15) there are trans-

\section{Figure 14 - First cracks identified in the slab elements - load of $101.35 \mathrm{kN}$}

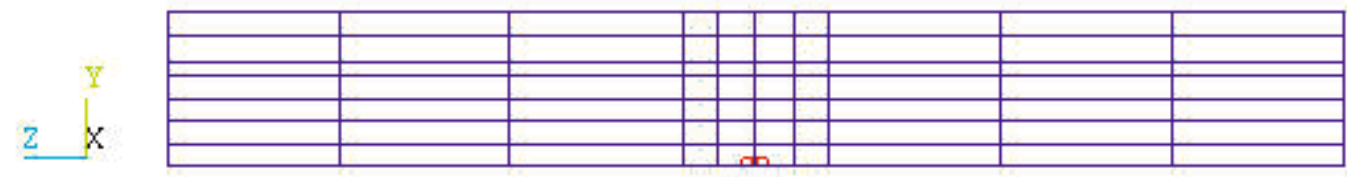

Frontal View

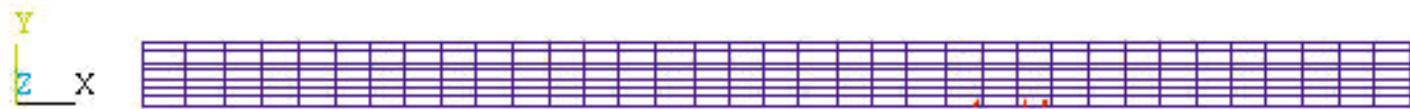

Lateral View

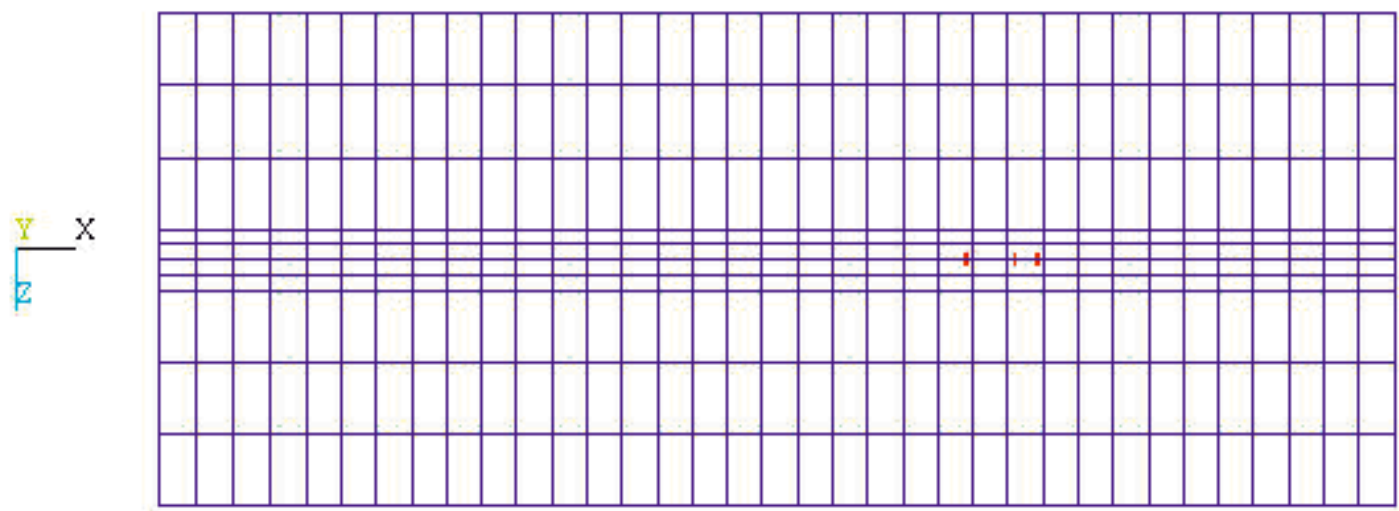

Superior View 
Figure 15 - Transversal cracks (Z direction), by shearing in slab - load of $151.45 \mathrm{kN}$

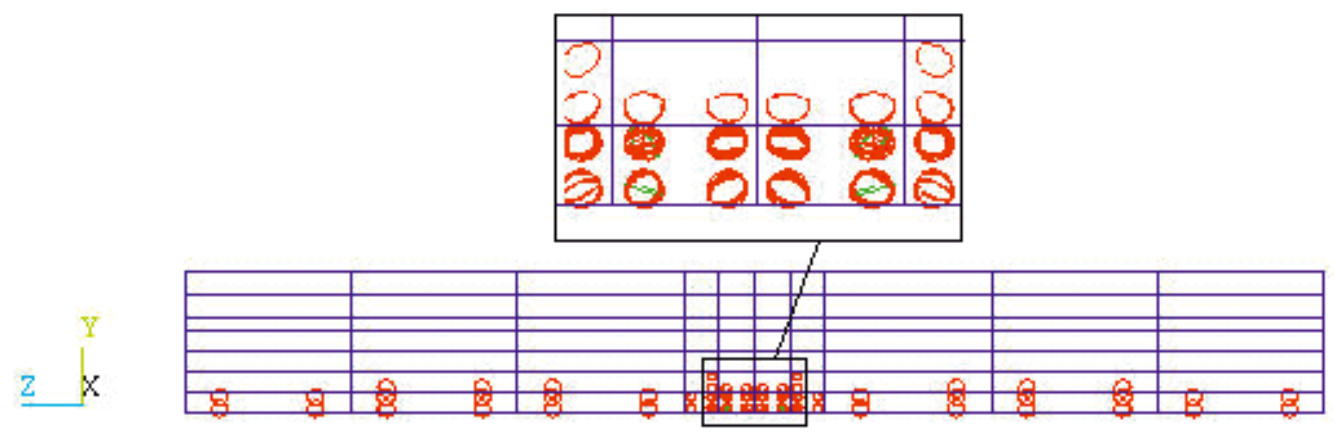

Frontal View

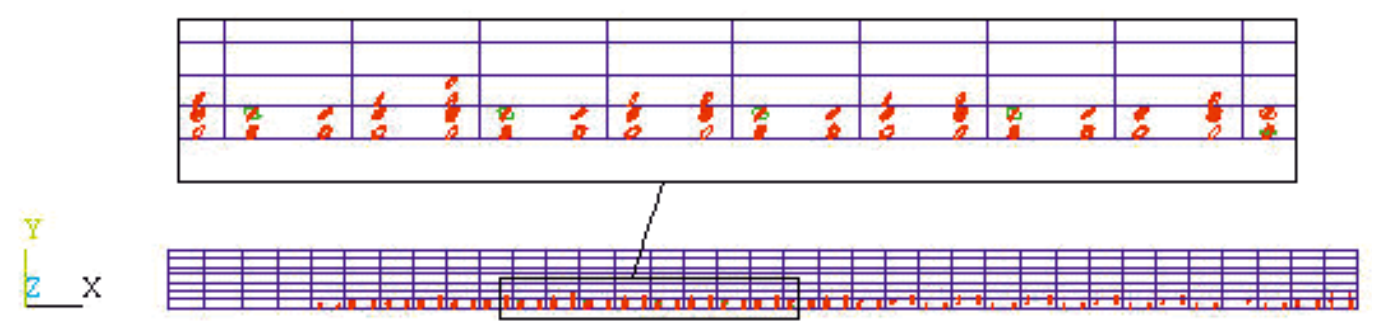
Lateral View

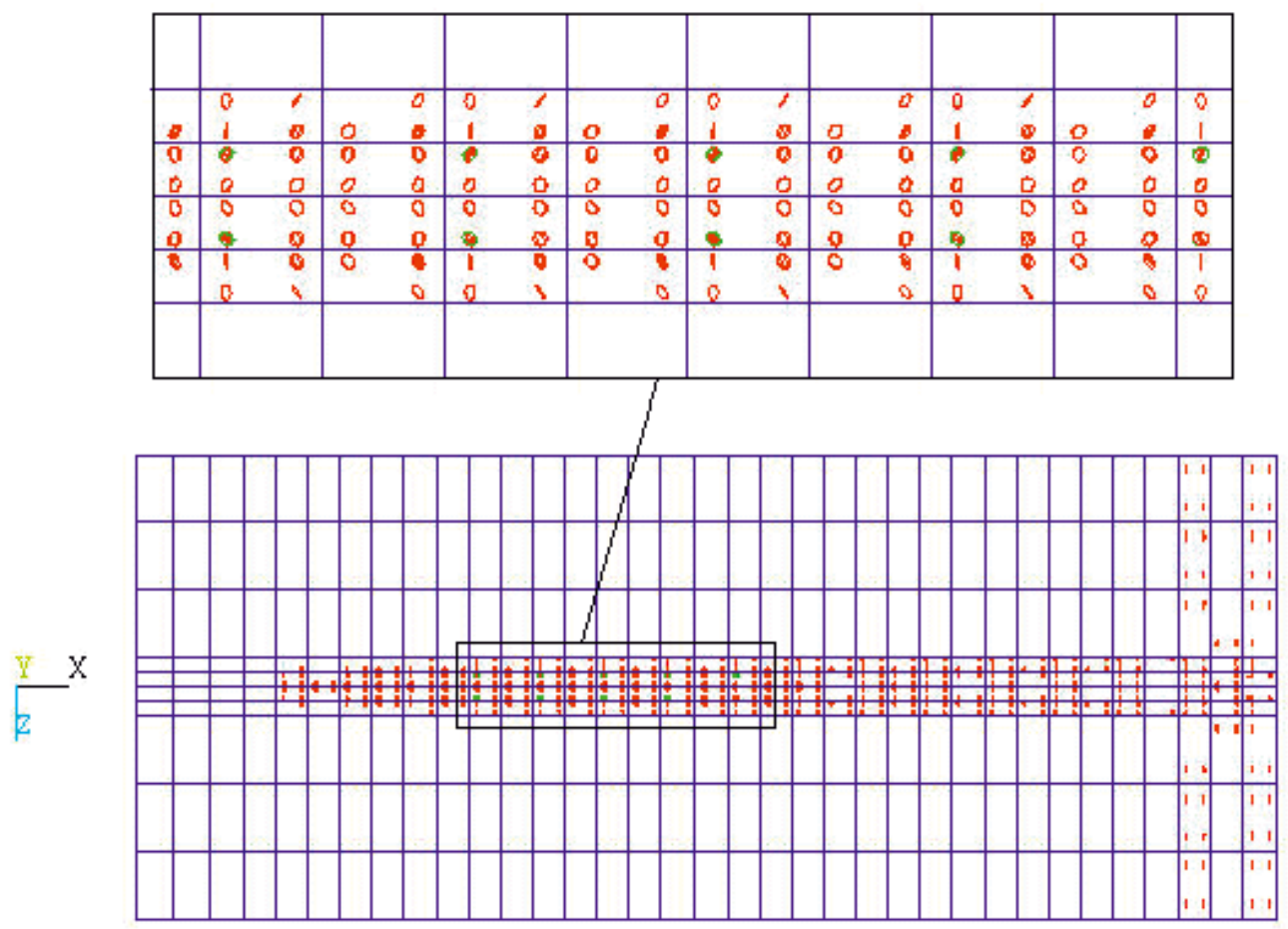

Superior View 
verse cracks identified ( $Z$ direction) in the slab-beam interface, from tensile longitudinal stresses. It was also observed, for this load level, the presence of longitudinal cracks ( $X$ direction), that initially occur in front of the connector and then behind it. These are shearing cracks. It was also possible to identify shear cracking, inclined 45 degrees in the elements of the concrete slab. Figure 16 shows the cracking state of the slab for a $481.46 \mathrm{kN}$ load, which corresponds to the loading last step achieved in the numerical simulation.

Tables 6 and 7 present the results obtained in the third stage of the simulation and in the calculation of composite beams, according to standard recommendations [2], whose procedure is in [12] for the limit load $\left(\mathrm{F}_{\max }\right)$ and the vertical displacement mid-span $\left(\mathrm{u}_{\max }\right)$.

It is noteworthy that the number of shear connectors and the other parameters (force, displacement) were defined in terms of the lower resistance between the concrete slab and the steel section. That is, according to standard recommendations [2], the values obtained for the vertical displacements and forces are independent of the diameter and height of the shear connectors; because, in this case, since the composite section of the adopted beam was the same for all simulated models and since the concrete resistance to rupture is lower than the connector capacity to resist shearing, the force and displacement are the same for both models.

Table 6 refers to results of composite beams with $19 \mathrm{~mm}$ diameter $(\varnothing)$ connectors as a function of a variation in height $(\mathrm{H})$, and Table 7 shows results of composite beams with $102 \mathrm{~mm}$ high $(\mathrm{H})$ connectors versus the variation in diameter $(\varnothing)$.

It can be seen from Tables 6 and 7 that the maximum force calculated by the NBR 8800 [2] is conservative, because it presents lower values than those obtained in the numerical simulation. The vertical displacements were much higher than those found in numerical simulations, indicating a more rigid behavior of simulated models and a more ductile performance of the calculated ones.

\section{Conclusions}

The first step of simulations aimed to validate the models developed in this work, by comparing them to experimental [6] and numerical results [11]. In this comparison, it was concluded that it is possible to represent fairly well the behavior of composite beams through computational modeling.

\section{Figure 16 - Cracks for the last step of load reached by beam - load of 481.46 kN}

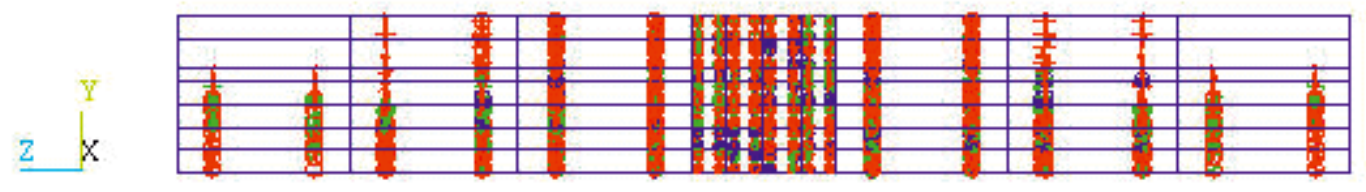

Frontal View

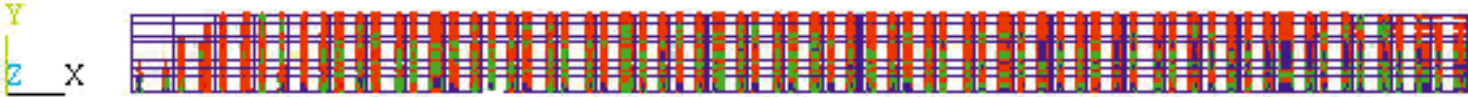

Lateral View

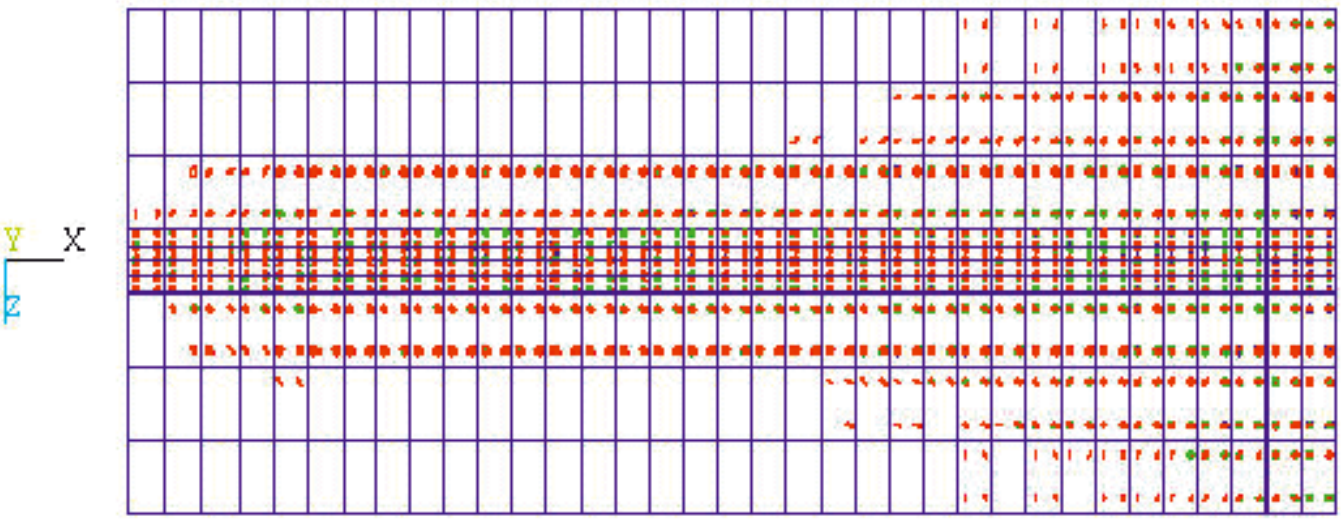

Superior View 
In the second stage of simulations, three diameters and three height values of for shear connectors were used, and it was observed that increasing the height of the connector does not necessarily increase the load limit, the vertical displacement and the longitudinal slip, but increasing the diameter of the connector increases the limit load, the vertical displacement and the longitudinal slipping in the slab-beam interface. In this stage it was still possible to visualize and analyze the state of cracking of the concrete slab due to the use of the SOLID 65 element.

In the third stage of simulations, there was a variation in the amount of shear connectors, while maintaining, for the adopted model, the same material properties and diameters and height variations of the second testing stage. The objective was to verify the influence of the number of connectors in the models by comparing results with those obtained in the second round of simulations, and evaluate the correspondence of numerical results to the standard one. Thus, the number of connectors was chosen in accordance with NBR 8800 [2] recommendations, whose calculations are presented in [12]. Therefore, by comparing the results obtained in the second and third stages, it was found that, in the elastic range, the results are similar regardless of quantity, diameter and height of the connectors. However, in the nonlinear range, the reduction in the number of connectors implies increase in longitudinal slip and has no preponderant influence on the strength and on the vertical displacement.

In comparing the values obtained from simulations to those calculated according to standard recommendations [2], it was noted that standard recommendations are conservative, because they provide lower values than those obtained in the simulations.

\section{References}

[01] ANSYS. Version 10.0 Documentation. ANSYS, Inc.

[02] ASSOCIAÇÃO BRASILEIRA DE NORMAS TÉCNICAS. NBR 8800 - Projeto de estruturas de aço e de estruturas mistas de aço e concreto de edifícios, Rio de Janeiro, 2008.

[03] ALVA, G. M. S.; MALITE, M. Comportamento estrutural e dimensionamento de elementos mistos aço-concreto. Publicação Interna: Cadernos de Engenharia de Estruturas - Escola de Engenharia de São Carlos, Universidade de São Paulo, vol. 7, n. 25,2005 , p. 51-84.

[04] CBCA - Centro Brasileiro da Construção em Aço. Características do sistema construtivo em aço. Available in:

$<h t t p: / / w w w . c b c a-i b s . o r g . b r / c a r a c t e r i s t i c a s . a s p>$. Access in: 10 June 2007.

[05] CHAPMAN, J. C. Composite construction in steel and concrete - the behaviour of composite beams. The Structural Engineer, v. 4, 1964, p. 115-125.

[06] CHAPMAN, J. C.; BALAKRISHNAN, S. Experiments on composite beams. The Structural Engineer, v. 42, 1964, p. 369-383.

[07] DAVID, D. L. Análise teórica e experimental de conectores de cisalhamento e vigas mistas constituídas por perfis de aço formados a frio e laje de vigotas pré-moldadas. São Carlos, 2007 Tese (doutorado) - Escola de Engenharia de São Carlos, Universidade de São Paulo, 250 p.

[08] FABRIZZI, M. A. Contribuição para o projeto e

\section{Table 6 - Comparative results of the beams with connectors $\varnothing=19 \mathrm{~mm}-\mathrm{NBR} 8800$ (1)}

\begin{tabular}{cccc} 
Beams with connectors $\emptyset=19 \mathrm{~mm}$ & $\mathrm{H}(\mathrm{mm})$ & $\mathrm{F}_{\max }(\mathrm{kN})$ & $\mathrm{u}_{\max }(\mathrm{cm})$ \\
Simulated Values & 76 & 466,78 & 4,80 \\
Calculated Values & 76 & $\downarrow 394,29$ & $\uparrow 14,38$ \\
Simulated Values & 88 & 488,12 & $\uparrow, 07$ \\
Calculated Values & 88 & $\downarrow 394,29$ & $\uparrow 14,38$ \\
Simulated Values & 102 & 502,30 & $\uparrow, 22$ \\
Calculated Values & 102 & $\downarrow 394,29$ & $\uparrow 14,38$ \\
\hline
\end{tabular}

\section{Table 7 - Comparative results of the beams with connectors $\mathrm{H}=102 \mathrm{~mm}$ - NBR 8800 (1)}

\begin{tabular}{|cccc|}
\hline Beams with connectors H=102 $\mathrm{mm}$ & $\varnothing(\mathrm{mm})$ & $\mathrm{F}_{\max }(\mathrm{kN})$ & $\mathrm{u}_{\max }(\mathrm{cm})$ \\
Simulated Values & 16 & 471,54 & 6,16 \\
Calculated Values & 16 & $\downarrow 394,29$ & $\uparrow 14,38$ \\
Simulated Values & 19 & 502,30 & 7,22 \\
Calculated Values & 19 & $\downarrow 394,29$ & $\uparrow 14,38$ \\
Simulated Values & 22 & 487,42 & 7,50 \\
Calculated Values & 22 & $\downarrow 394,29$ & $\uparrow 14,38$ \\
\hline
\end{tabular}


dimensionamento de edifícios de múltiplos andares com elementos estruturais mistos aço-concreto. São Carlos, 2007. Dissertação (mestrado) - Escola de Engenharia de São Carlos, Universidade de São Paulo, 233 p.

[09] GATTESCO, N. Analytical modeling of nonlinear behavior of composite beams with deformable connection. Journal of Constructional Steel Research, v. 52,1999 , p. $195-218$.

[10] KIRCHHOF, L. D. Uma contribuição ao estudo de vigas mistas aço-concreto simplesmente apoiadas em temperatura ambiente e em situação de incêndio. São Carlos, 2004. Dissertação (mestrado) - Escola de Engenharia de São Carlos, Universidade de São Paulo, 143 p.

[11] KOTINDA, T. I. Modelagem numérica de vigas mistas aço-concreto simplesmente apoiadas: ênfase ao estudo da interface laje-viga. São Carlos, 2006 Dissertação (mestrado) - Escola de Engenharia de São Carlos, Universidade de São Paulo, 116 p.

[12] MARCONCIN, L. R. Modelagem numérica de vigas mistas aço-concreto. Curitiba, 2008. Dissertação (mestrado) - Programa de Pós-Graduação em Construção Civil, Universidade Federal do Paraná, $154 \mathrm{p}$.

[13] OEHLERS, D.J. Splitting induced by shear connectors in composite beams. Journal of Structural Engineering, v.115, 1989, p.341-362.

[14] OVEN, V. A.; BURGESS, I. W.; PLANK, R. J.; ABDUL WALI, A. A. An analytical model for the analysis of composite beams with partial interaction. Computers \& Structures, v. 62, n. 3, 1997, p. $493-504$.

[15] TRISTÃO, G. A. Comportamento de conectores de cisalhamento em vigas mistas aço-concreto com análise da resposta numérica. São Carlos, 2002. Dissertação (mestrado) - Escola de Engenharia de São Carlos, Universidade de São Paulo, 125 p. 